\title{
Learning from the rubble: the case of Christchurch, New Zealand, after the 2010 and 2011 earthquakes
}

Melanie M. Bakema PhD Researcher, Faculty of Spatial Sciences, University of Groningen, The Netherlands, and PhD Researcher, Division of Geography and Tourism, Department of Earth and Environmental Sciences, University of Leuven, Belgium, Constanza Parra Professor, Division of Geography and Tourism, Department of Earth and Environmental Sciences, University of Leuven, Belgium, and Philip McCann Professor, Management School, University of Sheffield, United Kingdom

Learning after a disaster is crucial in creating more resilient places. However, many societies are repeatedly overwhelmed by disasters. This can be because of missed opportunities to learn in postdisaster settings or because of actions implemented that seem to be highly relevant to recovery in the short term, but potentially constrain aspirations in the longer term. This paper assesses learning processes among state and non-state actors and the ways in which these are bridged and scaled up to wider improvements in governance. Aiming to enrich understanding of postdisaster learning, it explores different actors' response actions after the earthquakes in Christchurch, New Zealand, in 2010 and 2011. On the one hand, 'learning by doing' is occurring, yet, on the other hand, systemic learning is hindered by mismatches between top-down steering and bottom-up initiatives. The study concludes that better linking and synergising of learning processes among different levels is vital for enhancing resilience in post-disaster societies.

Keywords: bottom-up initiatives, Christchurch, governance, learning, New Zealand, post-disaster recovery, resilience

\section{Introduction}

Disaster-affected societies often reveal a desire to see the adverse post-event situation as an opportunity to 'rebuild better'. Learning in the aftermath of a disaster can be a means to pave the way towards a 'better', more resilient society (Manyena et al., 20II). Both post-disaster recovery policies (see, for example, UNISDR, 20I5) and disaster scholarship (see, for example, Gaillard and Mercer, 20I2; Albright and Crow, 20I5) indeed stress the importance of post-disaster learning. During post-disaster recovery processes, affected communities acquire new experiences and develop knowledge. In this paper, learning within a disaster context is understood as the processes through which these experiences and knowledge are shared collectively and (eventually) transformed into governance improvements at the level of the society as a whole (Tidball et al., 20IO). In reality, however, the recurring cleaning up of disaster- 
related devastation reflects the difficulties that societies and their governments face in effectively upscaling these experiences and knowledge to more systemic learning that yields resilience and sustainability (Berkes, 2007). This suggests that the building of a more resilient post-disaster society encompasses the ability to transmit experiences, learned lessons, and needs from the different social groups exposed to damage and loss to the realm of governance of disasters.

The process of disaster recovery is just as important, if not more so, than the outcome, as already argued in the I990s. Where the outcome of post-disaster recovery mostly centres on the restoration of the built and physical environment, the process of recovery is more oriented towards social processes of learning and sociopolitical negotiation within communities (Nigg, I995). This is of course a complex process in which the effective upscaling of knowledge from the 'bottom' to the 'top' depends, to a large extent, on the capacity and willingness of the latter to embrace change and to integrate lessons and needs coming from the 'ground'.

This paper examines the role of learning as one of the principal components of resilience-building in post-disaster environments. It assesses this aspect by combining literature on resilience, learning, and multi-level governance of disasters, and using the case study of Christchurch, New Zealand, after the earthquakes in 20 IO and 20 II.

Resilience is a concept that increasingly is being referred to in scholarship on disasters and governance (Alexander, 2013). This paper bases its analysis on the vast and growing number of studies on resilience, particularly those that take a socialecological perspective. An oft-cited definition of resilience stems from such an approach (see, for example, Berkes and Turner, 2006; Folke et al., 20Io). Generally it is understood as:

(1) The capacity of linked social-ecological systems to absorb recurrent disturbances [. . .] so as to retain essential structures, processes, and feedbacks. [It] reflects (2) the degree to which a complex adaptive system is capable of self-organization [. . .], and (3) the degree to which the system can build capacity for learning and adaptation (Adger et al., 2005, p. I036).

Although resilience contains these three core components, research on this concept in a disaster context mainly focuses on absorbing and coping with a disturbance and tends to forget self-organisation cum capacity-building for learning (see, for example, IFRC, 20I6). As a result, only a limited number of studies deal with learning and its enabling conditions, as well as, more specifically, with the value of combining different types of knowledge for learning (see, for example, Gaillard and Mercer, 20I2).

Learning as part of resilience-building unfolds in a sequence of interrelated steps: there is a need to share collectively and discuss people's experiences, needs, and realities after a disaster, as a means to bridge the new concerns and knowledge that are produced among the citizens exposed to disasters. Upscaling this new knowledge towards higher governance scales and voicing social needs to the public sector hold the capacity to feed existing governance systems and enhance their ways of operating. 
From the standpoint of disaster governance, a multi-level governance system can stimulate dynamic interaction among the 'on-the-ground' mass of experiences and knowledge of communities, societal groups, and state actors (see, for example, Ahrens and Rudolph, 2006; Mitchell, 2006; Raju and Becker, 2013).

The Christchurch case study draws attention to the role of a variety of state and non-state actors in the collective construction or hindrance of a more fertile postdisaster learning ground. An in-depth qualitative analysis was conducted of recovery from the devastating earthquakes in the city and wider region, including two periods of fieldwork in 2012 and 2OI4. The findings reveal the separate emergence of ad hoc 'learning by doing' within different levels of government and societal groups. However, bridging and upscaling this 'learning by doing' into more systemic learning is hampered by existing mismatches between the priorities and actions of the different government levels and the bottom-up initiatives led by civil society entities. Although mismatches between higher and local-level actors are quite common, their consequences for disaster-prone places are very serious: they constitute an important driver within the spatial-temporal causation chain that transforms hazards into disasters. From the point of view of learning, the case study shows how discrepancies in the priorities and actions of different actors produce fragmented post-disaster learning groups that do not interact with each other, and knowledge that does not circulate widely, but instead remains constrained to certain groups.

In this light, this research provides insights into the roles of different actors in triggering (or hindering) learning processes, the ways in which these processes are paved, and how collective action that unfolds following a disaster contributes to (or not) the transition to a more resilient and sustainable society. It explores both the facilitation and the blockage of learning through the interactions between actors at different socio-political levels. Thus it contributes to enriched understanding of post-disaster learning processes and to debates on learning, resilience, and disaster governance.

Section two appraises current approaches to learning from theory with a spotlight on the meaning of learning within resilience in the context of disasters. Section three examines the case of Christchurch and the different domains in which learning is occurring after the earthquakes. It assesses the contribution of bottom-up initiatives to post-disaster recovery, as a key element of self-organisation and capacitybuilding to establish fertile ground for learning. The analysis of the literature and the Christchurch case study point up three core themes discussed in this paper:

- the shifting expectations of different actors over time with regard to governance;

- the importance of the pace and sequencing of post-disaster cycles and their governance processes; and

- the different types of multi-level learning processes that take place in parallel, and the degree to which they are bridged and scaled up to facilitate or impede learning.

Finally, the conclusion evaluates the ways in which learning develops in post-disaster locations, and what other places can learn from Christchurch vis-à-vis governance for enabling learning in a post-disaster setting. 


\section{Learning in disaster debates}

The United Nations Office for Disaster Risk Reduction (UNISDR, 20I7) defines a disaster as 'a serious disruption of the functioning of a community or society involving widespread human, material, economic or environmental losses and impacts, which exceeds the ability of the affected community or society to cope using its own resources'. This oft-cited definition is grounded in academic work on hazards and disasters from the second half of the twentieth century. As of this period, academics started to question the 'naturalness' of disasters. O'Keefe, Westgate, and Wisner (I976) argued that disasters are just as much (or perhaps even more so) the product of economic and social as natural factors. They stated that the growing number of disasters should be because of a combination of extreme natural events and vulnerable human populations. Disaster research has evolved further with a stronger focus on the social factor in the creation of disasters (Pelling, O’Brien and Matyas, 2015). In this regard, literature on topics such as resilience and vulnerability related to disasters has become vast and diverse (Wisner et al., 2004; Alexander, 20I6). Yet, some crucial themes, such as the endogenous societal causes leading to the social creation of disasters, remain under examined. These need to be developed further, instead of simply regarding disasters as threatening external events that can be managed (OliverSmith, 20I6). The effects of disaster politics and power relationships on resilience and vulnerability constitute a second understudied domain (Alexander, 20I6). This relates, for instance, to the questions raised by Davoudi (2OI2) and others regarding 'resilience for whom'. A third aspect deserving more attention concerns changing expectations and the needs of people in the aftermath of disasters. Understanding the changing geographical and temporal variety of needs is critical to generating governance processes that match the pace and sequencing of different post-disaster phases. Finally, a theme that is almost absent in resilience studies is the influence of learning practices - individual, collective, and at various spatial levels - on the extent to which more systemic or societal learning is enhanced (or hindered).

\section{Resilience in disaster recovery}

Nigg (I995) emphasised that the process of disaster recovery is just as important as the outcome, if not more so, and hence the social processes of recovery should not be overshadowed by a focus on the restoration of the built environment. Although affected communities usually aim to regain their pre-disaster ways of life, pre-disaster patterns and societal characteristics influence the development of post-disaster recovery problems. To learn from the past, the conditions that contributed to the growth of a disaster need to be identified, critically evaluated, and hopefully changed. For this to occur, it is important to know the various realities and experiences of affected actors (Nigg, I995).

Another attempt to include the social factor in the analysis of disasters has its roots in a social-ecological systems approach. This perspective starts from the assumption that societal systems are entangled with their natural environments, with human 
action in coevolution with nature (Berkes, 2007). Social-ecological systems scholars have furthered the analysis on disasters by integrating social and natural causes into one framework that also incorporates the concept of resilience (see, for example, Adger et al., 2005). Resilience comes from the Latin word 'resilire', meaning to spring back, but it gained prominence with the rise of systems thinking in the I96os and when Holling (I973) applied it to ecology. In the field of ecology, the ability to absorb shocks and retain the same form and function is said to determine the resilience of a system (Alexander, 20I3). Further elaborating on this concept, social-ecological systems defined resilience as 'the ability of complex social-ecological systems to change, adapt, and, crucially, transform in response to stresses and strains' (Davoudi, 20I2, p. 302). From this dynamic understanding, the concept reflects a shift from regarding the world as orderly and predictable towards a place that is chaotic, complex, and uncertain (Davoudi, 20I2). Disasters across the planet are examples of this, notably in the way in which they recall recurrently the limitations of societies in controlling the forces of nature, and the associated consequences. Post-disaster recovery processes can also be seen as an opportunity to improve the conditions that might have led to a disaster, and particularly to transition to a situation where resilience is enhanced and vulnerability diminished simultaneously (Manyena et al., 20I I). From this perspective, the resilience metaphor of 'bouncing back' to a pre-disaster stage can be considered as a mistake or at least as a contradiction that forgets the large and diverse learning potential within circumstances of stress.

Disaster practice, though, is still lagging behind in operationalising an approach to resilience that fully encapsulates the opportunity for learning. This can be observed in the United Nations Office for Disaster Risk Reduction's definition of resilience in the context of disasters as 'the ability of a system, community or society exposed to hazards to resist, absorb, accommodate to and recover from the effects of a hazard in a timely and efficient manner, including through the preservation and restoration of its essential basic structures and functions' (UNISDR, 20I7). The emphasis here is on the ability of societies to 'bounce back' to the pre-disaster situation in the shortest possible time frame, which is the vision prominent in economic and engineering discourses on resilience (Handmer and Hilman, 2004). The quest to restore, or even the possibility of doing so, the 'normal', pre-shock situation after a disturbance builds on the assumption that the world is static, in contrast to mounting contemporary recognition that societies are dynamic. The emphasis on 'bouncing back' underscores the outcome of recovery rather than the process, and reflects the dominance of emergency management in disaster response (Manyena et al., 20I I; Jones, Manyena, and Walsh, 20I5). Hence, evaluating and measuring the disaster resilience and vulnerability of communities often are privileged at the expense of longer-term multi-level (re)development approaches and learning efforts (Cutter et al., 2008; Tierney, 20I2).

The message conveyed in the World Disasters Report 2016 on resilience by the International Federation of Red Cross and Red Crescent Societies (IFRC, 20I6) seems more promising. It stresses that 'bouncing back' is actually never desired or possible, and thus recovery processes need to be tailored towards adaptation and, especially, 
transformation. 'Adaptability' and 'transformability' are two related key elements of social-ecological resilience through which learning by a society can be triggered (Folke et al., 20IO). Adaptability is understood as 'the capacity of a social-ecological system to learn, combine experience and knowledge, adjust its responses to changing external drivers and internal processes, and continue developing within the current stability domain' (Folke et al., 20IO, p. 2I), whereas transformability means 'the capacity to create a fundamentally new system when ecological, economic, or social structures make the existing system untenable' (Folke et al., 20Io, p. 23). Knowledge of longer-term recovery processes and sustainability goals is important for societies to adapt and transform and it is gaining more prominence in disaster studies (see, for example, Ahrens and Rudolph, 2006; Mitchell, 2006; Raju and Becker, 2013). Yet, qualitative approaches to the social dimensions of recovery processes, such as the ability of societies to self-organise and build capacity to enable learning, are still waiting to be unpacked further (Pelling, O’Brien, and Matyas, 2015).

\section{Conceptualising learning}

Learning has been approached from different points of view and by different fields of inquiry (Armitage, Marschke, and Plummer, 2008; Albright and Crow, 2015). According to the Oxford Dictionary (20I7), learning is to ' $[\mathrm{g}]$ ain or acquire knowledge of or skill in (something) by study, experience, or being taught'. Since the late I970s, the concept has been adopted increasingly in the fields of environmental management (Kilvington, 2007), governance and planning (Pahl-Wostl, 2009), and socialecological systems (Adger et al., 2005). According to Berkes (2007), learning occurs through the storing of experiences and knowledge of past events in the memories of individuals and communities. Learning is grounded, therefore, in the identities of individuals and communities, and it is place-based and time-sensitive (Rodrik, 20I4). Tidball et al. (20IO) argue, furthermore, that individual and collective values, knowledge, and experiences have to be navigated up to the level of communities and institutions to improve higher-level governance systems. Interest in learning is reflected in several calls for experimentation and innovation to deal with the challenges of an uncertain and unknown future (Reed et al., 20IO). From this standpoint, learning can be seen as an exploratory search process in which actors collectively experiment and trigger innovation (Pahl-Wostl, 2009; Mehmood and Parra, 20I3).

One essential action to enhance a grasp of learning is to emphasise on which levels and among which actors it occurs. Learning can develop on an individual, community, institutional, or a more systemic level. As such, it encompasses the question of how societal groups learn. According to Tidball et al. (2010, p. 595), learning in groups happens through 'social interaction [. . .] and through iterative feedback between learners and their environment resulting in changes in both'. Armitage, Marschke, and Plummer (2008) conceptualise a trichotomy of experiential, transformative, and social learning. Experiential learning is applicable to group processes, but considered as a process of creating knowledge through the transformation of experience 
on an individual basis; transformative learning, subsequently, concentrates on the move from critical reflection on individual's experiences to action; and social learning arises when experiences and ideas are shared with others.

Our preferred definition of learning is the one offered by Tidball et al. (2010) and thus forms the basis of this study on resilience in post-disaster situations. This definition touches on the dynamic social relationships through which post-disaster 'learning by doing' experiences are or can be turned into more systemic learning. When learning of wider society happens, improvements in governance processes for the future or for other contexts have the potential to be realised. Certainly, learning for resilience through the upscaling of knowledge is not a mechanical 'ABC process' (Shove, 20IO); rather, learning is complex, dynamic, and faces several barriers. This is especially the case in post-disaster settings, as such events stress and push different social groups and institutions to the limit (Donahue and Tuohy, 2006). On the one hand, citizens suffer the material consequences of a disaster, as well as going through a social and personal reconstruction of perceptions and expectations along with the recovery process. On the other hand, learning becomes problematic at an institutional level given the limited exchange of feedback between state and non-state actors on different levels (Meyer, 20IO). The production of knowledge will only lead to systemic learning when institutions are open enough to incorporate ideas coming from below and embrace change.

\section{Learning in disaster governance for more resilient and sustainable societies}

A disaster affects the material conditions of societies, disrupts the lives, emotions, and behaviour of many people, and challenges societal organisation and governance. Pre-disaster societal characteristics, as well as the different types of societal responses in the aftermath of a disaster, have a direct bearing on how the post-disaster situation will unfold. For instance, a chaotic post-disaster situation, characterised by organisations deficient in the capabilities to address the new challenges, weak leadership, and an erratic division of responsibilities between actors, has a greater chance of exacerbating the impacts (see, for example, Wisner et al., 2004; Quarantelli, Lagadec, and Boin, 2007; Aldrich, 2012).

Governance refers to the roles and responsibilities of different state and non-state actors, and the power dynamics between them, on different spatial and temporal scales (see, for example, Swyngedouw, 2005; Parra and Moulaert, 2016). Understanding of the value of multi-level governance and collaborative processes in post-disaster situations has evolved in several ways. In disaster studies, the shift from government to governance is reflected in the passage from (central) government-led disaster management to disaster governance and disaster risk reduction with a sharing of governance roles between a range of state and non-state actors (Tierney, 2012). In particular, there is growing recognition that disaster prevention and recovery require different types of knowledge, including technical expert and local community knowledge (Oliver-Smith, 20I6). Post-disaster recovery with a reliance on (top-down) 
state-led policies has 'largely failed to prevent the occurrence of disasters, thus prompting practitioners supported by some social scientists to suggest an alternative, bottom-up framework for reducing disaster risk' (Gaillard and Mercer, 20I2, p. 97). Although technical knowledge and command-and-control measures are needed, such as in the emergency phase after a disaster, more room is expected to be given to bottom-up initiatives and collaborative planning mainly in the later stages (Berkes and Folke, 2002). Moreover, one would expect the range of knowledge generated during and after a disaster to be included in decision-making pertaining to disaster planning, and considered when developing preparedness and preparing for future emergencies. In this way, the needs, wishes, and values of different actors will help to guide recovery processes in a more socially optimal way.

The time dimension of a disaster is another crucial aspect of governance and learning in the post-disaster recovery period. Warning systems to inform societies early about the possibility of a natural hazard are becoming increasingly erudite, yet they cannot prevent the unexpected arrival of a disaster, such as an earthquake. The recovery processes that follow are generally characterised by a mosaic of organisations dedicated to emergency response efforts (IFRC, 20I6). Frequently, however, tensions exist within these processes between the short-term, urgent relief needs of people and longer-term redevelopment aims (Jha et al., 20I0; OECD, 2013). Governance in the early phases of abrupt change thus tends to be primarily intuitive and less analytical and consultative in nature (Bonn and Rundle-Thiele, 2007). Moreover, disasters trigger new opinions and perceptions among affected communities, which have an effect on place attachment dynamics and the value ascribed to hometowns and neighbourhoods. Post-disaster collective emotions, fears, feelings of uncertainty, and losses of different kinds lead in many cases to the emergence of new solidarity networks and to other societal groups providing support. This mixture of material and nonmaterial transformations triggered by disasters, during the different phases of the disaster cycle, converts despair into hope and shifts expectations, on the one hand, and challenges existing (disaster) governance systems, on the other (Quarantelli, I995). Experiences, obstacles, governance mismatches, and hope-despair tensions play a major role in knowledge-building within post-disaster recovery processes (Pelling, O'Brien, and Matyas, 2015). Moreover, the chaotic and ad hoc decision-making characterising the post-disaster phase leaves little room for public engagement and for more serious collective reflection on recovery (Bonn and Rundle-Thiele, 2007; Schad et al., 20I2). As discussed above, the Christchurch case reveals that early optimism and participation may be inadvertently dampened or even quashed by poor sequencing of participatory governance processes or by dysfunctional multi-level interactions between different actors. Dynamic and context-sensitive governance arrangements that ensure a good balance between short- and longer-term needs and aspirations are still implemented rarely by state actors, despite them being necessary conditions for learning, resilience, and sustainability (Ingram et al., 2006; Spijker and Parra, 20I8). 
An optimal dialogue between the plurality of state and non-state actors, operating at different spatial levels, is another essential component of disaster governance (Albright and Crow, 20I5; Pahl-Wostl, 2009; Parra, 20I0). Such articulation involves state authorities and alliances between state actors and the private sector, as well as different civil society groups. The literature contains several examples of initiatives by civil society groups, highlighting their importance for learning in different postdisaster contexts (see, for example, Fois and Forino, 20I4). From this perspective, public engagement and participation are very significant, as they permit and stimulate the social interaction required for the reproduction of knowledge (Gaillard and Mercer, 20I2). Furthermore, public engagement is a fundamental step towards bridging and creating synergies between the different disaster experiences and forms of knowledge held by different actors. The big question that remains to be answered is how to connect better 'on-the-ground' experiences with actors at higher spatial levels? A crucial condition for this is knowledge and learning flows feeding into the improvement of wider governance arrangements and a transition towards more resilient and sustainable post-disaster places (Pradel, García, and Eizaguirre, 20I3).

Another key issue in disaster studies concerns the integration of sustainability aims into the recovery process. Increasingly, the idea of enabling a holistic recovery process encompasses promoting a post-disaster transition to a more sustainable and resilient society (Mitchell, 2006; Fois and Forino, 20I4). Learning as part of resilience is one of the means through which societies can satisfy longer-term sustainability aspirations (see, for example, Asprone and Manfredi, 20I4; Lockie, 20I6). Sustainability aims differ from resilience objectives mainly in the sense that they focus on how the disaster can be used to transition to a more sustainable society - that is, how societies can 'bounce forward' (see, for example, Lockie, 20I6). Ultimately, when governance is trusted to state, private, and civil society actors, the integration of sustainability aims into the recovery processes that are offered in a post-disaster setting is more likely to succeed (Lockie, 20I6). However, there remains a gap between emphasising the importance of different kinds of knowledge and social engagement and its actual incorporation in the practice of disaster governance (Gaillard and Mercer, 2OI2).

\section{Methodology and post-event responses to enable learning}

This research on learning after the two major earthquakes and many aftershocks that Christchurch and surrounding areas on the south island of New Zealand experienced in 2010 and 2OI (Hayward, 20I3; Saunders and Becker, 20I5) is based on two periods of fieldwork in 2012 and 20I4, during which I6 and 24 in-depth interviews were performed, respectively. The respondents were selected because of their involvement in the recovery process as officials at different levels of government (such as the Christchurch City Council (CCC) and the Canterbury Earthquake Recovery Authority (CERA)), people from the private sector (such as the Canterbury Business 
Leaders Group (CBLG)), research institutes (such as Lincoln University), and community representatives and grassroots organisations (such as Gap Filler and several neighbourhood associations). Six respondents were interviewed during both periods of fieldwork, because of their changing positions in the post-earthquake phase. All interviews were based on prior informed consent and were recorded, transcribed, and coded. In addition, the lead author observed various public information sessions and participated in activities organised by grassroots bodies.

For the purpose of this analysis, and following the literature on learning, this study posits that there are primarily three domains of learning. These are distinguished using three actor groups whose post-disaster responses contribute to a greater or lesser extent to capacity-building, learning, and, consequently, resilience: state actors; the private sector and civil society; and society as a whole. Here, civil society captures both pre-existing community organisations and new grassroots organisations that emerged in response to the earthquakes. Furthermore, the study discerns three channels of engagement between the different actors in the multi-level governance system: public participation led by the government; public engagement through pre-existing community organisations; and public engagement through newly established grassroots organisations (see Table $\mathrm{I}$ ).

The analysis of learning in Christchurch begins by looking briefly at the role of state actors in the recovery process. It explores the division of governance roles between the different levels of government, and reflects critically on how the earthquakes 'shaked' the division of responsibilities between the government levels, and the relationships with the private sector and the civil society. This is followed by an examination of the responses of the second and main analytical category, the private sector and civil society, with a focus on learning dynamics among wider societal systems springing from a diverse set of community and grassroots initiatives. The paper assesses the reinvention of the city that is mainly taking place by these civil society groups and considers the interactions between different actors among whom learning is enabled or hindered. Lastly, attention is directed to learning of society as a whole through the creation and spread of knowledge. By investigating the transition of the city from the short to the longer term, the study considers the shift from adaptation to transformation in relation to sustainability, on the one hand, and reflects on the interpretations of resilience and sustainability by the different actors in Christchurch, on the other. For ease of exposition and understanding, Figure I provides a simple schematic of the timings, actions, and roles of different (groups of) actors.

\section{Table 1. Domains of learning and channels for multi-actor engagement}

\section{Domains of learning}

- State actors

- Private sector and civil society

- Society as a whole
Channels for multi-actor engagement

- Public participation led by the government

- Public engagement through pre-existing community organisations

- Public engagement through newly established grassroots organisations

Source: authors. 
Figure 1. Schematic timeline of the establishment of selected actors and institutions since September 2010

\begin{tabular}{|c|c|c|c|}
\hline Actors & $\begin{array}{c}\text { Emergency situation } \\
\text { After September } 2010 \text { and } \\
\text { February } 2011\end{array}$ & $\begin{array}{l}\text { Short- and medium-term } \\
\text { recovery } \\
\text { Between } 2011 \text { and } 2014\end{array}$ & $\begin{array}{l}\text { Medium- and long- } \\
\text { term recovery } \\
\text { After } 2014\end{array}$ \\
\hline State actors & $\begin{array}{l}\text { Main focus on } \\
\text { Christchurch }\end{array}$ & $\begin{array}{l}\text { Canterbury Earthquake } \\
\text { Recovery Authority } \\
\text { and Christchurch City Council: } \\
\text { focus on Christchurch }\end{array}$ & $\begin{array}{l}\text { Canterbury Earthquake } \\
\text { Recovery Authority: focus on } \\
\text { Canterbury; Christchurch City } \\
\text { Council: focus on Christchurch }\end{array}$ \\
\hline $\begin{array}{c}\text { Central } \\
\text { government }\end{array}$ & $\begin{array}{l}\text { Strong, leading role; set up } \\
\text { of Canterbury Earthquake } \\
\text { Recovery Authority }\end{array}$ & $\begin{array}{l}\text { Strong, leading role; } \\
\text { top-down }\end{array}$ & $\begin{array}{l}\text { Smaller role; transferring } \\
\text { to local governments }\end{array}$ \\
\hline $\begin{array}{c}\text { Local } \\
\text { government }\end{array}$ & $\begin{array}{l}\text { Strong role; } \\
\text { relief efforts }\end{array}$ & $\begin{array}{l}\text { Medium role; balancing with } \\
\text { Canterbury Earthquake } \\
\text { Recovery Authority }\end{array}$ & $\begin{array}{l}\text { Stronger role; focus on } \\
\text { sustainability }\end{array}$ \\
\hline Other & $\begin{array}{c}\text { Strong role of Civil } \\
\text { Defense New Zealand }\end{array}$ & $\begin{array}{l}\text { Increasing public } \\
\text { engagement }\end{array}$ & $\begin{array}{l}\text { Increasing collaboration } \\
\text { with civil society }\end{array}$ \\
\hline $\begin{array}{l}\text { Private sector } \\
\text { and civil } \\
\text { society }\end{array}$ & $\begin{array}{l}\text { Main focus on } \\
\text { neighbourhoods and outer } \\
\text { suburbs }\end{array}$ & $\begin{array}{l}\text { Community organisations } \\
\text { focus on neighbourhoods; } \\
\text { grassroots on city center }\end{array}$ & $\begin{array}{l}\text { Tailored spatial focus } \\
\text { depending on type of } \\
\text { project or activity }\end{array}$ \\
\hline $\begin{array}{l}\text { Community } \\
\text { organisations }\end{array}$ & $\begin{array}{l}\text { Helping and assisting in } \\
\text { their neighbourhoods }\end{array}$ & $\begin{array}{l}\text { Organising activities; } \\
\text { communication to } \\
\text { Canterbury Earthquake } \\
\text { Recovery Authority }\end{array}$ & $\begin{array}{l}\text { Re-orientating their roles } \\
\text { in their neighbourhoods }\end{array}$ \\
\hline $\begin{array}{c}\text { Grassroots } \\
\text { organisations }\end{array}$ & No-existing & $\begin{array}{l}\text { Mobilising people; } \\
\text { temporary activities }\end{array}$ & $\begin{array}{l}\text { Creative activities; big role } \\
\text { in transitional city }\end{array}$ \\
\hline Other & No-existing & $\begin{array}{c}\text { Set up of Canterbury } \\
\text { Communities' Earthquake } \\
\text { Recovery Network; linking }\end{array}$ & $\begin{array}{l}\text { Bottom-up initiatives } \\
\text { increasingly recognised }\end{array}$ \\
\hline
\end{tabular}

Source: authors.

\section{Findings: diversity of learning in post-disaster Christchurch}

Some five years after the earthquakes, Christchurch was still the scene of construction sites, with cranes across the skyline and government officials conducting damage assessments. Many people in the city argue that recovery is not occurring fast enough and wish that the government would involve them more in the process (respondents from CanCERN (Canterbury Communities' Earthquake Recovery Network), Gap Filler, and WeCan (Wider Earthquake Communities Action Network), 2012 and 20I4). Yet, on the contrary, many positive developments have resulted mainly from grassroots initiatives. For instance, the city was ranked as a main place to visit by Lonely Planet ${ }^{\mathrm{I}}$ and The New York Times ${ }^{2}$ in 2013-I4 and international media often portray Christchurch as an exemplar of a recovery process. The following subsection examines the response actions led by state actors, the private sector, and civil society, and appraises what the interactions between these initiatives and processes have to say about the missing links between the aim to 'rebuild better' to create a more resilient and sustainable society, and the reality in post-disaster Christchurch. 


\section{The state actors that hinder capacity-building in the civil society}

Before the earthquakes in Christchurch in 2010 and 20II, three local governments were responsible for the area that was to be devastated: Christchurch City Council; Selwyn District Council; and Waimakariri District Council. The earthquakes yielded changes in the governance system that had to deal with the consequences of the events. The first earthquake (in September 2010) led to the appointment of one commissioner for earthquake recovery; there were no other changes to the organisation of the public sector. After the second more devastating earthquake (in February 20II), however, the central government of New Zealand declared an emergency situation in Christchurch and the response was managed by the Ministry of Civil Defence and Emergency Management. Owing to the overwhelming impact of this earthquake, the central government decided to set up a special-purpose government unit to lead the recovery process: CERA, operating under the Canterbury Earthquake Recovery Act 20I I (CERA, 20I2). When the initial relief situation and the civil defence emergency period came to an end, the earthquake response and recovery roles and responsibilities were shared between CERA, the three local governments, and other local authorities (respondents from the CCC and CERA, 20I2). ${ }^{3}$ In this constellation of state institutions, CERA was the government authority responsible for leading the recovery process and coordinating local tiers of government. Although special-purpose units are valued and criticised internationally (Bakema et al., 20I7; FEMA, 20I7), people in Christchurch asserted that CERA was too powerful and not engaging enough with residents and other local stakeholders (respondents from CanCERN and Gap Filler, 20I2 and 20I4). Twenty-nine of the study respondents shared this view, as illustrated by one from Lincoln University (20I4):

I think, my sense is that the central government has come in too big and too heavy, out of panic, to be honest.

The reasons for this can be found in the public participation activities that the government organised during the recovery phase, regarded here as the first channel through which people could engage in the recovery process. A few months after the February 2OI I earthquake, the government launched the 'share an idea' campaign via which people could share their thoughts concerning the future of the city. Later, there were several other participation activities, such as 'tell us what you think', and people were given the opportunity to submit their views about the recovery plans. The input from these activities informed the recovery strategies for the city (respondents from the CCC and CERA, 20I2). Whereas the people regarded the first 'share an idea'4 project as very successful and innovative, they became increasingly frustrated as time passed when they did not see their contributions in the plans. They blamed the state and especially CERA for not really enabling participation or for interacting only with people at higher levels, instead of with people 'on the ground' (Amore, Hall, and Jenkins, 20I7; respondents from the CBLG, Gap Filler, and the Mount Pleasant community organisation, $20 \mathrm{I} 2$ and 2OI4). 
The perceptions of people in Christchurch are varied of the roles and responsibilities of the different levels of government. All of the study respondents seemed to agree that a top-down, special-purpose unit to lead recovery (CERA) was necessary, contrary to some debate in the field of disaster studies that pre-existing institutional structures frequently should remain in charge (see, for example, Mitchel, 2006). In Christchurch, there was a need, especially in the early phases after the earthquakes, for one higher-level government body to guide and coordinate lower tiers of government and other agencies (respondents from the CCC, Gap Filler, and Lincoln University, 2OI2 and 2OI4). Nevertheless, II respondents from, inter alia, CanCERN (20I4) and the CCC (2OI4), as well as a local member of parliament (2OI4), thought that the intervention in the local context of a special-purpose unit, which was also an elected government ministry, produced a recovery process that was too politically determined and dominated by one powerful institution. This led to a situation in which decisions made by CERA were hard to accept by a city governed by a different political party, ${ }^{5}$ regardless of whether or not it liked the plans: '[s]o, you kind of not only have two separate organisations, but there're also different ideologies underlying them, which creates the tensions' (respondent from the CCC, 2OI4). Moreover, eight respondents from the CCC and Gap Filler (2OI2 and 20I4), among others, claimed that a special-purpose unit should be able to clear obstacles facing lower tiers of government and civil society and facilitate their projects. In reality, though, I r respondents criticised CERA for only establishing more bureaucracy, as echoed by a researcher from Lincoln University (2014):

And maybe they [CER A] need to be clearer about what it is they are achieving. But they're seen as a, they're not seen as an enabling, they're seen, at best as a mystery and at worst some obstacle to recovery.

In sum, the earthquakes triggered governance changes that were implemented successfully and unsuccessfully in an environment of institutional confusion. On the one hand, there was a duplication of roles and responsibilities between public institutions; on the other hand, many roles were left unfilled (respondents from the CCC and Life in Vacant Spaces (LiVS), 2OI4). The post-earthquake actions of state actors hampered the creation of new learning opportunities, as they were not sufficiently aligned to draw synergies among them. The scale and magnitude of the earthquakes, together with the frustrating role of the government, triggered the selforganisation of people in community and grassroots organisations.

\section{Civil society responses nurture the ground for learning}

Civil society (the second domain of learning), inspired by dissatisfaction and the unfulfilled wish to play a more significant role in recovery, structured itself into preexisting and new organisations - the study's second and third channels for engagement. The public perception and the nature of these two types of actors was rather different. Whereas pre-existing community organisations concentrated principally 
on coping at the neighbourhood level, the newly established grassroots organisations were experimenting with new projects in the city centre. Their different point of focus, but equal drive (triggered by shared needs and wishes), highlights the importance of diversity in post-earthquake responses for learning.

\section{Pre-existing community organisations}

Most of the pre-existing community organisations were established long before the earthquakes. As neighbourhood associations they served the interests of residents, communicated with government and private (housing) agencies, and arranged community activities. They attract predominantly young families and middle-aged and older people. After the earthquakes, these groups reoriented their actions (respondents from Aranui, Mount Pleasant, New Brighton, and Sumner community organisations, $20 \mathrm{I} 2$ and 2OI4). In the early days following the disaster, pre-existing community organisations became the most important social groups at the community level. When people came together in their streets, helping each other during the emergency, community organisations were the first ones to provide 'on-the-ground' assistance and a comfort zone (respondent from Project Lyttelton and an independent journalist, 20I4; also see Lindell et al., 20I6).

As for longer-term recovery, community-building activities at the neighbourhood level also appeared to be highly valuable for adapting to the new situation in a resilient manner. Community organisations such as Aranui, Lyttelton, Mount Pleasant, New Brighton, and Sumner became very active and devoted their actions to helping people and to organising a variety of events, such as farmers' markets and music festivals (respondents from the Aranui community organisation and Project Lyttelton, 20I4). The organisations identified a need for community (re)building, and so they continued with their activities and to offer assistance in the longer term. Furthermore, some of them expanded their role, becoming, for instance, members of the community forum of CERA that was set up in 20I I (respondents from the Mount Pleasant community organisation and Project Lyttelton, 20I4). Nevertheless, a respondent from Project Lyttelton (2OI4) noted with respect to the community forum of CERA that: '[i]t is hopeless, it has got no power, so it does have community representatives on it, but they feel disempowered by the whole process too. [. . .] So, they are just token. [. . .] They cannot do anything'. All six community organisation interviewees pointed out that the different local governments encouraged their initiatives, yet their actions did not develop into widespread learning owing to the limited recognition received from CERA. Community organisations doubted whether CERA attached importance to their activities, especially in the first three years of recovery (respondents from CanCERN and the Mount Pleasant community organisation, 20I2).

New social relationships arose in the post-earthquake context (Quarantelli, I995), which resulted, for instance, in neighbours getting to know their social environment better. However, the top-down approach of the central government allied with limited multi-actor engagement channels led to widespread dissatisfaction regarding the 
ways in which the different levels of government valued and encouraged the actions of community groups. The evidence of this study suggests that insufficient effort to upscale and incorporate community experiences and knowledge in wider governance systems resulted in early bottom-up optimism and energy being replaced later by disillusion and scepticism. This deflated the expectations of people, although it did not prevent the emergence of many community groups leading socially innovative endeavours.

\section{Grassroots organisations in the 'transitional city'}

The third channel for engagement, part of the second domain of responses of the private sector and civil society, consists of the grassroots organisations that were set up in response to the earthquakes in Christchurch. Their flourishing activities are mainly the product of dissatisfaction among people about the central governmentled recovery process. Triggered by the wish to be more engaged in recovery, primarily young people started to lead and to develop all kinds of cultural, creative, and environmentally-friendly activities. The variety of the mainly temporal activities reintroduced life into the devastated city centre and is one of the key reasons why Christchurch keeps attracting tourists (respondents from Gap Filler and Greening the Rubble, 2OI 2 and 20I4). These initiatives often are regarded as part of the 'transitional city'. This view of the city was first presented by the grassroots organisations to inspire central and local government. Later, it was adopted by the local tiers of government and followed by CERA with the aim of making the best of the city in the transitional period from the earthquakes until the completion of recovery (respondents from Gap Filler, Greening the Rubble, Lincoln University, and LiVS, $2 \mathrm{OI} 2$ and 2OI4).

One of the biggest grassroots organisations, Gap Filler, is a very important actor in the city. For instance, it organises open-air cinemas, mini golf, and the 'pallet pavilion', a popular multifunctional outdoor cafe (see Figure 2). Another grassroots organisation is Greening the Rubble, which has created green spaces in empty lots, including community gardens in which people come together. Furthermore, every year the group called FESTA (Festival of Transitional Architecture) organises a free, public festival around urban regeneration in the challenging and dynamic postearthquake city (respondents from Gap Filler, 20I4). By arranging all sorts of activities, these organisations are redeveloping Christchurch and making it a pleasant place to live in again (respondents from Gap Filler and LiVS, 20I4).

The projects of Gap Filler and Greening the Rubble, inter alia, became very successful and needed a growing number of locations. Land use permits were required for the temporary use of the empty land; they had to be granted by the CCC. Such processes posed many bureaucratic hurdles to the grassroots organisations, leading to the establishment of LiVS, an umbrella entity set up to negotiate and tackle administrative difficulties (respondents from Gap Filler and LiVS, 20I4). This example highlights the evolution of the grassroots organisations, and the maturity and level 
Figure 2. Pallet pavilion

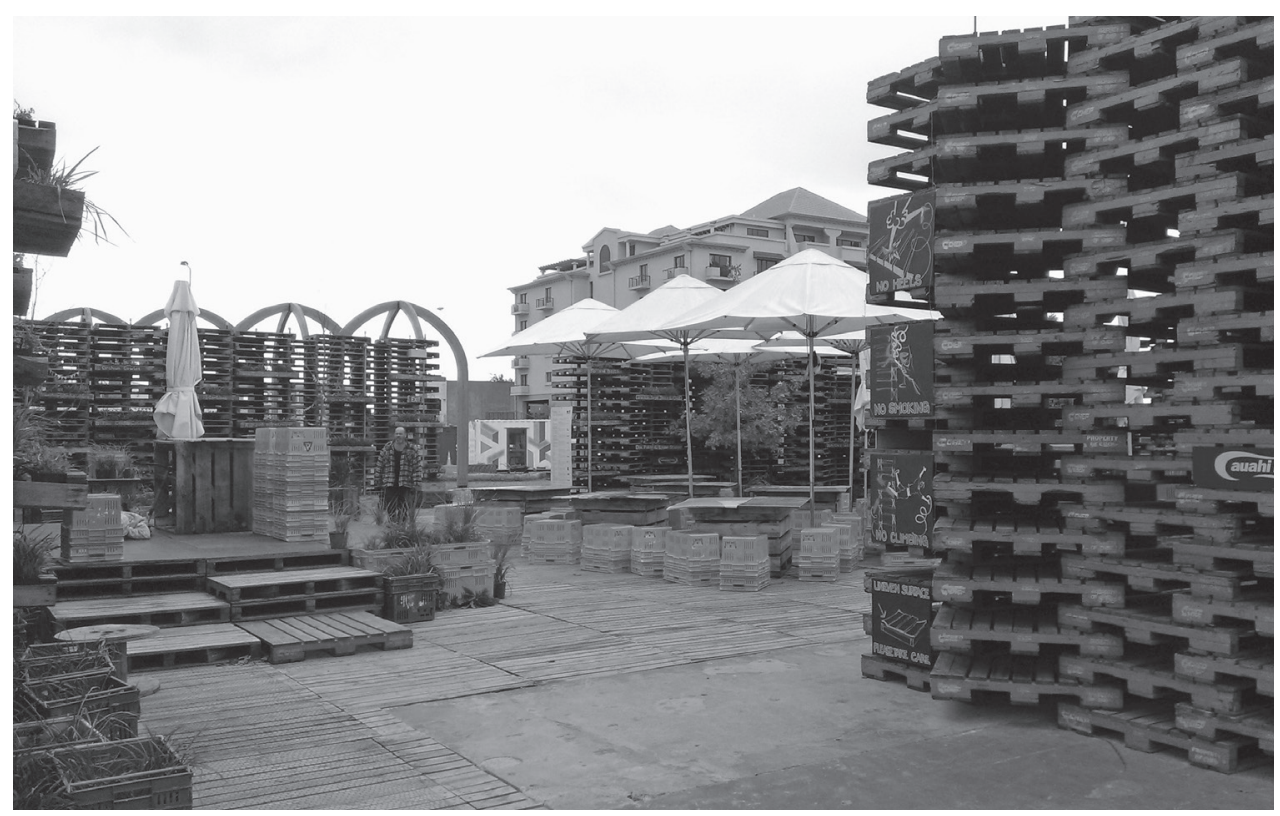

Source: authors.

of formality attained. Since 20I4, LiVS has had a fulltime employee paid for by the CCC to facilitate communication with the public sector and to clear the way for civil society initiatives. Furthermore, civil society members gave rise to organisations such as CanCERN and WeCan with the aim of assisting residents with communications and negotiations with state actors. Moreover, the Student Volunteer Army played a major role in relief efforts, helping affected students and the wider Christchurch population in the early days after the earthquakes. Indigenous Maori communities in Christchurch also received particular attention from community organisations. The community organisation of Aranui-a neighbourhood where a large proportion of the local Maori community, Ngai Tahu, lives-represented the interests of this group. In addition, the Maori mental health community tailored its activities to helping Maori recovering from the earthquakes (respondents from the Aranui community organisation and Lincoln University, 20I4). The bridging role that these organisations acquired in the longer term is illustrated, for instance, by the fact that two members of CanCERN are fulltime and are paid for by CERA (respondents from CanCERN, Lincoln University, and WeCan, 20I2 and 20I4).

As for the private sector, it launched the Re:Start mall initiative in the city centre (see Figure 3). The inner city centre completely lost its retail function after the earthquakes, and so shop owners presented the idea of moving their businesses out of their destroyed buildings and into a new, temporary, shopping area. The new retail centre consisted of sea containers, in which the shops were located, and its development contributed to the creation of a new, lively city centre (respondents from Gap Filler, 2012 and 2OI4). 
Figure 3. Re:Start mall

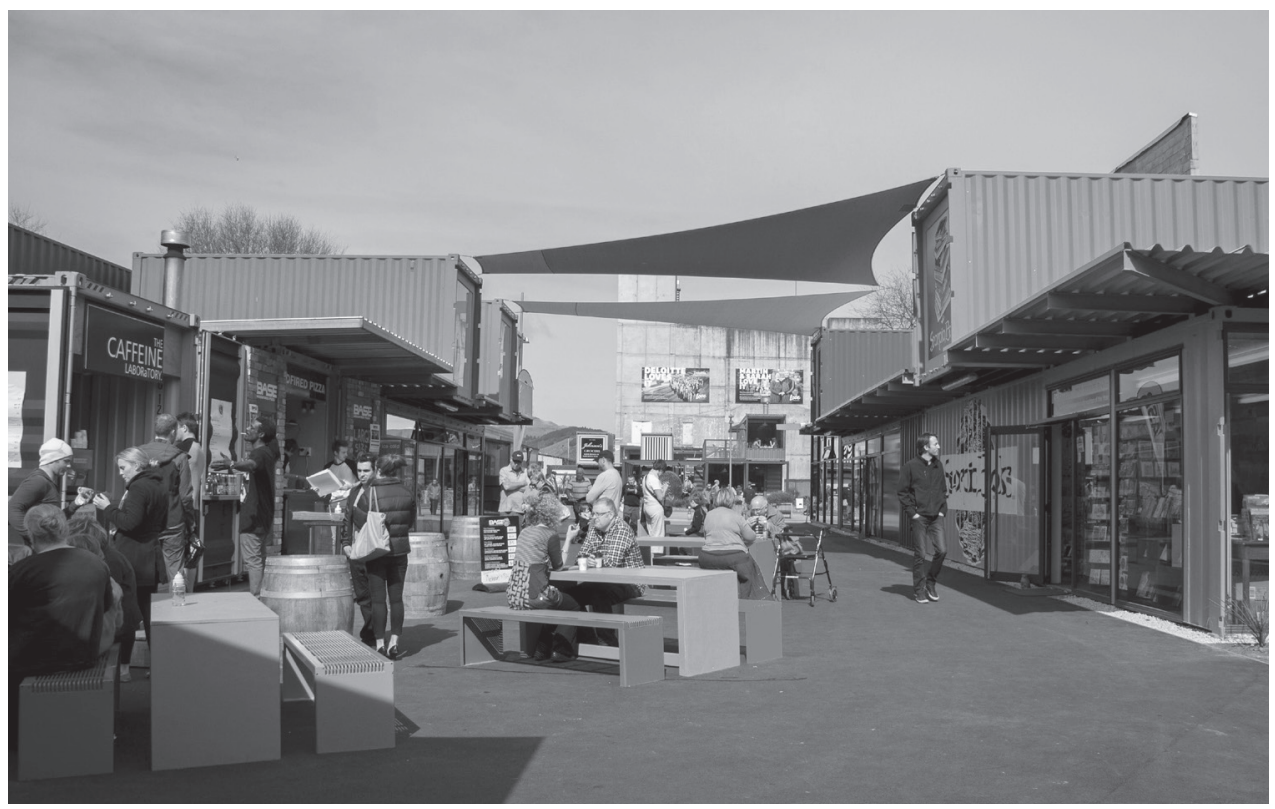

Source: authors.

The temporary projects in the transitional city of Christchurch are important from many points of view. From a cultural dimension, they give people the opportunity to experiment with innovative ideas and to reimagine their city. This (re-)engagement with the city allows people to foster and reconstruct their place attachment and to reinterpret the values they append to the city. From a planning standpoint, the temporary activities contribute to the enhancement of peoples' perceptions of a certain area. And from an economic viewpoint, they bring people and money back to the city centre (respondents from the CCC, Gap Filler, and Greening the Rubble, 20I2 and 20I4). By so doing, these temporary projects help to transform negative postdisaster experiences into opportunities for community (re)building and learning. In other words, the initiatives of these grassroots organisations are leading to a wider learning process, transmitting experiences to higher-level systems.

The organisations made it their mission to keep people attached to their city while it was in transformation, to make the best of the transitional period, to be a real voice in communicating with state actors, and to show state actors the value of their activities. In this way, the bottom-up post-earthquake actions shifted and became wider learning processes, as they enabled and encouraged people to look together for innovation in an uncertain future and to upscale their experiences and knowledge. Although central and local government increasingly recognise the value of temporary activities, reflected, for instance, in some fulltime positions at grassroots organisations being financed with public money, the civil society groups are still demanding more acknowledgement of their work in the recovery process (respondents from the CCC and LiVS, 20I4). 
As recovery progresses, the grassroots organisations will either obtain a more permanent status and/or will reorient their mission. Even though five study respondents claimed that momentum for people to invest their energy in the recovery is lost, it cannot be denied that the civil society initiatives are the main driver of capacitybuilding and learning in Christchurch (respondents from Gap Filler, 20I4).

\section{Learning of society as a whole}

This third learning domain includes aspects pertaining to the shift from coping in the early aftermath of a disaster towards adaptation and transformation that are likely to spawn resilient and sustainable paths of development. The study reflects on the interpretations of resilience and sustainability in Christchurch of actors on different levels, as there are factors that both hinder and enable the upscaling of learning processes.

In policy documents and visions for the future, the different levels of government in Christchurch underline the intention to use the earthquakes as an opportunity to rebuild more sustainably in economic, environmental, and social terms. This objective is among others reflected in initiatives to encourage people to rebuild their houses in a more energy-efficient fashion (CERA, 20I2). With regard to the physical aspects of post-disaster learning, Christchurch adopted new building codes and zoning regulations. For instance, the maximum height of buildings was lowered in 2013 from six to four stories and new earthquake-proof building rules were produced (respondents from the CCC, 2OI4). Furthermore, since many areas of Christchurch suffered liquefaction as a result of the earthquakes, several are zoned differently now and are not destined for residential functions anymore. Apropos learning and the goal of rebuilding more sustainably, the CCC appointed a sustainability coordinator (respondents from the CCC, 20I4), who is responsible for advising the city council on the integration of sustainability principles into the recovery of the city. In addition, Christchurch launched the 'Target Sustainability' fund for residents who want to incorporate sustainability measures so as to strengthen their property (respondents from the CCC, 20I4).

The inflexibility of (house) insurance schemes, however, hampers such improvements. Many respondents in Christchurch emphasised that they cannot move forward with their own recovery process because they have to wait years for their damage assessments and insurance claims to be processed by the national Earthquake Commission (EQC). In many cases, moreover, insurance schemes only allow for the recreation of the pre-damage state, not for any improvement measures or sustainable alternatives (respondents from the Aranui community organisation, Lincoln University, and WeCan, 20I4). Without going into further detail, one should note that the insurance schemes are a key issue in that they block people's aspirations to rebuild their houses more sustainably, and trap residents who want to sell their house. In other words, they thwart a more systemic shift towards a sustainable city.

Nevertheless, some signs of change can be observed among central and local government. In the words of a respondent from the CCC (20I4): 
The central government threw that out and said: 'Oh, we don't need that sustainability rubbish, no'. And so, this current government is backtracking a lot on the sustainability features. [. . .] They're starting to be more receptive to green city ideas.

This includes a movement towards a more collaborative approach:

We've gone from command and control, and I think, command and control for the first phase makes sense. But we've gone beyond that now, we're talking about collaboration, and co-creation, and whole lot about that dynamics need to play. Because let's face it, CER A cannot build the whole city. [. . .] It's about getting hearts and minds. It's about creating a vision which is attractive to new investment across the world. And, the green story is part of that (respondent from the CCC, 20I4).

In terms of multi-level learning, it remains to be seen whether the community and grassroots organisations have the power to strengthen their role in inspiring and triggering deeper sustainable transformation in Christchurch, or whether they will be limited to enriching the transitional period with flourishing cultural and creative activities facilitated by government.

\section{Linking bottom-up and top-down responses for learning}

The findings presented above suggest that there are opportunities for learning on a wide range of fronts in Christchurch and that incremental learning is occurring among state actors, the private sector, and civil society. Learning as part of resiliencebuilding, though, seems to be frustrated in a deeper, more structural way. The possibilities to channel the experiences and knowledge of civil society into more systemic learning often are missed owing to deficient interaction and engagement between actors on different institutional levels. Notably, since the central and local tiers of government do not work together sufficiently, and at times even conflict with each other, principally because of their political differences, opportunities for collaboration among state agencies frequently are missed. Furthermore, the community and grassroots organisations do not seem to be encouraged by the institutional and political environment - in fact, they appear to be rather discouraged by it.

As for the pace and sequencing of governance processes, different phases of the recovery process are evident (that is, emergency, response, reconstruction, and recovery). Whereas civil society organisations were active in the emergency and response phases, they seem not to be welcome in the same way in the reconstruction and recovery phases. Consequently, there is a risk of them having less influence on resilience and sustainability transformations in the longer term. This undermines their capacity to upscale and disseminate the necessary context-sensitive knowledge for an inclusive and sustainable learning process (Lockie, 20i6).

As discussed, multi-level governance embodies several levels through which learning can develop (Swyngedouw, 2005; Parra and Moulaert, 20I6). These levels refer 
to the multi-actor, temporal, and spatial dimensions of governance. Integrating different actors, from different areas, and at different times before and after a disaster, can help to generate governance arrangements that are context-sensitive (Bakema et al., 20I7). This is a crucial step in enabling the necessary social interaction from which learning experiences can be bridged, synergised, and scaled up. The evidence of this study suggests that the post-earthquake recovery process in Christchurch is inattentive to these multi-actor, temporal, and spatial dimensions of a multi-level governance system, mostly because civil society is prevented from interacting with state and private entities. The lack of multi-actor engagement aimed at disseminating and bridging knowledge and experiences is hindering, therefore, the upscaling of learning.

It is important to clear this blockage and to stimulate a transition from ad hoc 'learning by doing' to learning by wider governance systems (Pradel, García, and Eizaguirre, 20I3). The mobilisation of social groups has a momentum that needs to be seized at an exact moment in time, making adequate pacing and sequencing of governance processes very important. Particular 'disaster moments' appear to have their own needs and there are critical turning points where these needs for different types of governance constellations between state actors, the private sector, and civil society change. If the governance approach of the emergency management phase is extended during the later reconstruction phase, for instance, capacity-building in this next stage can be harmed. Ongoing opening up of spaces for collaboration by the government and adequate management of the shifting expectations of people are important for further enabling and linking learning processes.

\section{Conclusion}

To acquire a deeper understanding of post-disaster learning as part of creating more resilient places, this study assessed the response actions of various state and non-state actors. In particular, it contributes to enhancement of understanding of the endogenous societal causes that lead to the social creation of disasters. The study examined the ways in which the experiences and knowledge of different actors are bridged to create synergies, and are scaled up to wider improvements in governance. The case of Christchurch shows that learning processes are taking place among different actors, but often they are isolated and not transformed into more systemic learning. In particular, the imbalance between progress on a high level and progress on a lower level raises the question of how to create a post-disaster dynamic governance context. This mismatch between the recovery of the city and the individual situations of people recalls the importance of an adequate balance between top-down steering and bottom-up initiatives, opening up opportunities for improvements in the short term that also are good for the long term.

In terms of the pace and sequencing of post-disaster governance processes led by the state, the authority and responsibilities accorded to CERA made this central 
government ministry too powerful, not independent and not engaged enough with local tiers of government, or with the people. What one can learn from this is that governance roles and responsibilities should be devolved early and to a great extent to local tiers of government in place, and they should involve the private sector and civil society. A kind of multi-actor 'umbrella organisation' would be suitable to navigate the recovery processes, together with other governmental actors and agencies, and to empower these local entities. Such an umbrella organisation could play an important role in conveying experiences, bridging knowledge, and thus facilitating learning processes.

Furthermore, in terms of shifting the expectations of actors, people's frustrations about the government, as well as their wish for greater engagement with the recovery process, stimulated the flourishing of both pre-existing community groups and newly established grassroots organisations. The evidence from Christchurch reveals that these civil society initiatives are very valuable for keeping people attached to their city, helping them adapt to the new reality, relaunching the local economy, being an official voice vis-à-vis the public institutions, and, moreover, setting the ground for transformation, from which learning and hence resilience can grow.

Experience and knowledge for establishing greater resilience after a disaster can be widespread among an assortment of actors in society, but they are not able to lead to more mature and robust systemic learning if they are not shared or scaled up. To enrich understanding of social learning processes and inherent politics in postdisaster situations, it is important to define whether there is a place for social and technical learning at the same time.

What is more, how can connections between the different (contradictory or mutually enforcing) aims of resilience and sustainability be enhanced during recovery processes? Since all actors have different and important experiences and forms of knowledge, response actions by the state, the private sector, and civil society and their interactions have to be facilitated to create synergies and to become opportunities for wider learning. Although technical learning is happening in Christchurch, such as via the new building codes and zoning regulations, the better allocation and distribution of roles and the more democratic sharing of governance responsibilities remain unfinished processes.

As analyses and understanding of disasters are developing, it may well be the case that the concepts and frameworks used evolve on the basis of new societal learning. Ultimately, this can help to foster transitions from ad hoc learning to wider learning of governance systems around the world.

\section{Acknowledgements}

The research for this manuscript was funded by the Ubbo Emmius Fund of the University of Groningen and was sponsored by the University of Leuven (Interne Fondsen KU Leuven, grant number STGI4/O22). The paper is the product of two 
research visits to Christchurch, New Zealand. The authors would like to express their gratitude to the Agribusiness and Economics Research Unit (AERU) of Lincoln University, Canterbury, for its support and useful insights. The in-depth fieldwork would not have been possible without the opportunity to be hosted by the AERU. Special thanks are owed, therefore, to Professor Paul Dalziel and Professor Caroline Saunders. Moreover, the authors would like to thank all of the participants in the city of Christchurch and surrounding areas for their willingness to share their experiences.

\section{Correspondence}

Melanie M. Bakema, The Faculty of Spatial Sciences, University of Groningen, Landleven I, 9747 AD Groningen, The Netherlands. Telephone: +3I (o) 50363 7748; e-mail:m.m.bakema@rug.nl

\section{Endnotes}

I See both http://www.lonelyplanet.com/new-zealand/travel-tips-and-articles/7753I and https:// www.businessinsider.com/lonely-planet-top-IO-cities-of-2OI3-2OI2-IO? IR=T (last accessed on 8 November 2018).

2 See http://www.nytimes.com/interactive/20I4/or/ro/travel/20I4-places-to-go.html?_r=o (last accessed on 8 November 20I8).

3 For a more extensive discussion of the institutional setup of CERA, see, for example, Hayward (2013) and Bakema et al. (2017).

4 'Share an idea was a conversation with our community to gather ideas on how they wanted their Central City redeveloped following the devastating February 20 I earthquake'. See https://www. ccc.govt.nz/the-council/plans-strategies-policies-and-bylaws/share-an-idea (last accessed on 8 November 20I8).

5 At the time of the earthquakes, the Labour Party was the most favoured party in Christchurch; former Labour Party Member of Parliament Lianne Dalziel won the city's mayoral election in 2013. In contrast, the National Party was the biggest party in the central government of New Zealand, delegating as well the minister for CERA, Gerry Brownlee. This divided political situation contributed to tensions between the central (CERA) and the local government (CCC) and between the private sector and civil society (based on interviews with respondents from CCC, CERA, Gap Filler, and Lincoln University, 2012 and 20I4).

\section{References}

Adger, W.N., T.P. Hughes, C. Folke, S.R. Carpenter, and J. Rockström (2005) 'Social-ecological resilience to coastal disasters'. Science. 309 (5737). pp. I036-I039.

Ahrens J. and P.M. Rudolph (2006) 'The importance of governance in risk reduction and disaster management'. Journal of Contingencies and Crisis Management. I4(4). pp. 207-220.

Albright, E.A. and D.A. Crow (20I5) 'Learning processes, public and stakeholder engagement: analyzing responses to Colorado's extreme flood events of 2013'. Urban Climate. I4(I). pp. 79-93.

Aldrich, D.P. (2012) Building Resilience: Social Capital in Post-Disaster Recovery. University of Chicago Press, Chicago, IL. 
Alexander, D.E. (2013) 'Resilience and disaster risk reduction: an etymological journey'. Natural Hazards and Earth System Sciences. I3 (II). pp. 2707-27I6.

Alexander, D.E. (2016) 'The game changes: "disaster prevention and management" after a quarter of a century'. Disaster Prevention and Management. 25(I). pp. 2-IO.

Amore, A., C.M. Hall, and J. Jenkins (2017) 'They never said "come here and let's talk about it": exclusion and non-decision-making in the rebuild of Christchurch, New Zealand'. Local Economy. $32(7)$. pp. 617-639.

Armitage, D., M. Marschke, and R. Plummer (2008) 'Adaptive co-management and the paradox of learning'. Global Environmental Change. I8(I). pp. 86-98.

Asprone, D. and G. Manfredi (20I4) 'Linking disaster resilience and urban sustainability: a glocal approach for future cities'. Disasters. 39(I). pp. 96-III.

Bakema, M.M., C. Parra, P. McCann, P. Dalziel, and C. Saunders (2017) 'Governance in shaky societies: experiences and lessons from Christchurch after the earthquakes'. Environmental Policy and Governance. 27(4). pp. 365-377.

Berkes, F. (2007) 'Understanding uncertainty and reducing vulnerability: lessons from resilience thinking'. Natural Hazards. 4I(2). pp. 283-295.

Berkes, F. and C. Folke (2002) 'Back to the future: ecosystem dynamics and local knowledge'. In L.H. Gunderson and C.S. Holling (eds.) Panarchy: Understanding Transformations in Human and Natural Systems. Island Press, London. pp. I2I-I46.

Berkes, F. and N.J. Turner (2006) 'Knowledge, learning and the evolution of conservation practice for social-ecological system resilience'. Human Ecology. 34(4). pp. 479-494.

Bonn, I. and S. Rundle-Thiele (2007) 'Do or die - strategic decision-making following a shock event'. Tourism Management. 28(2). pp. 6I5-620.

CERA (Canterbury Earthquake Recovery Authority) (2012) Christchurch Central Recovery Plan. http:// ceraarchive.dpmc.govt.nz/sites/default/files/Documents/christchurch-central-recovery-planmarch-20I4.pdf (last accessed on 5 December 20I8).

Cutter, S.L. et al. (2008) 'A place-based model for understanding community resilience to natural disasters'. Global Environmental Change. i8 (4). pp. 598-606.

Davoudi, S. (2012) 'Resilience: a bridging concept or a dead end?' Planning Theory and Practice. I3 (2). pp. 299-333.

Donahue, A.K. and R.V. Tuohy (2006) 'Lessons we don't learn: a study of the lessons of disasters, why we repeat them, and how we can learn them.' Homeland Security Affairs. II (2). pp. I-28.

FEMA (Federal Emergency Management Agency) (2017) 'About the agency'. http://www.fema.gov/ about-agency (last accessed on I2 November 20I8).

Fois, F. and G. Forino (20I4) 'The self-built ecovillage in L'Aquila, Italy: community resilience as a grassroots response to environmental shock'. Disasters. 38(4). pp. 719-739.

Folke, C. et al. (20Iо) 'Resilience thinking: integrating resilience, adaptability and transformability'. Ecology and Society. I5 (4). pp. 20-28.

Gaillard, J.C. and J. Mercer (2OI2) 'From knowledge to action: bridging gaps in disaster risk reduction'. Progress in Human Geography. 37(I). pp. 93-II4.

Handmer, J. and M. Hillman (2004) 'Economic and financial recovery from disaster'. The Australian Journal of Emergency Management. I9(4). pp. 44-50.

Hayward, B.M. (2013) 'Rethinking resilience: reflections on the earthquakes in Christchurch, New Zealand, 2010 and 20II'. Ecology and Society. I8(4).pp. 37-42.

Holling, C.S. (1973) 'Resilience and stability of ecological systems'. Annual Review of Ecology and Systematics. 4 (November). pp. I-23.

IFRC (International Federation of Red Cross and Red Crescent Societies) (2016) World Disasters Report 2016 - Resilience: Saving Lives Today, Investing for Tomorrow. Imprimerie Chirat, Lyon, France. 
Ingram, C., G. Franco, C. Rumbaitis-del Rio, and B. Khaizai (2006) 'Post-disaster recovery dilemmas: challenges in balancing short-term and long-term needs for vulnerability reduction'. Environmental Science and Policy. 9(7-8). pp. 607-613.

Jha, A.K., J.D. Barenstein, P.M. Phelps, D. Pittet, and S. Sena (2010) Safer Homes, Stronger Communities: A Handbook for Reconstructing after Natural Disasters. The World Bank, Washington, DC.

Jones, S., B. Manyena, and S. Walsh (20I5) 'Disaster risk governance: evolution and influences'. In A.L. Collins et al. (eds.) Hazards, Risks, and Disasters in Society. Elsevier, Amsterdam. pp. 46-6I.

Kilvington, M. (2007) 'Social learning as a framework for building capacity to work on complex environmental management problems'. https://www.landcareresearch.co.nz/publications/research pubs/Social_learning_review.pdf (last accessed on I2 November 2018).

Lindell, M.K. et al. (20I6) 'Immediate behavioural responses to earthquakes in Christchurch, New Zealand, and Hitachi, Japan'. Disasters. 40 (I). pp. 85-III.

Lockie, S. (20I6) 'Beyond resilience and systems theory: reclaiming justice in sustainability discourse'. Environmental Sociology. 2(2). pp. II5-II7.

Manyena, S.B., G. O'Brien, P. O'Keefe, and J. Rose (2011) 'Disaster resilience: a bounce back or a bounce forward ability?'. Local Environment. I6(5). pp. 417-424.

Mehmood, A. and C. Parra (2013) 'Social Innovation in an unsustainable world'. In F. Moulaert, D. MacCallum, A. Mehmood, and A. Hamdouch (eds.) The International Handbook on Social Innovation: Collective Action, Social Learning and Transdisciplinary Research. Edward Elgar, Cheltenham. pp. 53-66.

Meyer, R. (2010) 'Why we still fail to learn from disasters'. In E. Michel-Kerjan and P. Slovic (eds.) The Irrational Economist: Making Decisions in a Dangerous World. Public Affairs Books, New York, NY. pp. I24-I3I.

Mitchell, J.K. (2006) 'The primacy of partnership: scoping a new national disaster recovery policy'. The ANNALS of the American Academy of Political and Social Science. 604(I). pp. 228-255.

Nigg, J.M. (1995) Disaster Recovery as a Social Process. Preliminary Paper No. 219. Disaster Research Center, University of Delaware, Newark, DE.

O'Keefe, P., K. Westgate, and B. Wisner (1976) 'Taking the naturalness out of natural disasters'. Nature. $260(5552)$. pp. 566-567.

OECD (Organisation for Economic Co-operation and Development) (2013) Policy Making after Disasters: Helping Regions Become Resilient - The Case of Post-earthquake Abruzzo. OECD, Paris.

Oliver-Smith, A. (2016) 'Disaster risk reduction and applied anthropology'. Annals of Anthropological Practice. 40 (I). pp. $73-85$.

Oxford Dictionary (2017) 'Learn'. https://en.oxforddictionaries.com/definition/learn (last accessed on I2 November 20I8).

Pahl-Wostl, C. (2009) 'A conceptual framework for analysing adaptive capacity and multi-level learning processes in resource governance regimes'. Global Environmental Change. I9 (3). pp. 354-365.

Parra, C. (20I0) 'Sustainability and multi-level governance of territories classified as protected areas: the Morvan regional park case'. Journal of Environmental Planning and Management. 53(4). pp. 49I-509.

Parra, C. and F. Moulaert (20I6) 'The governance of the nature-culture nexus: literature, case-studies and lessons to learn from the San Pedro de Atacama case'. Nature and Culture. 3 (September). https:// www.berghahnjournals.com/view/journals/nature-and-culture/I I/3/nature-and-culture. II. issue-3.xml (last accessed on I2 November 2018).

Pelling, M., K. O’Brien, and D. Matyas (2015) 'Adaptation and transformation'. Climatic Change. I33(I). pp. II3-I27.

Pradel, M., M. García, and S. Eizaguirre (2013) 'Theorizing multi-level governance in social innovation dynamics'. In F. Moulaert et al. (eds.) The International Handbook on Social Innovation: Collective Action, Social Learning and Transdisciplinary Research. Edward Elgar, Cheltenham. pp. I55-I68. 
Quarantelli, E.L. (1995) Emergent Behaviors and Groups in the Crisis Time of Disasters. Preliminary Paper No. 226. Disaster Research Center, University of Delaware, Newark, DE.

Quarantelli, E.L., P. Lagadec, and A. Boin (2007) 'A heuristic approach to future disasters and crises: new, old and in-between types'. In H. Rodríguez, E.L. Quarantelli, and R.R. Dynes (eds.) Handbook of Disaster Research. Springer, New York, NY. pp. I6-4I.

Raju, E. and R. Becker (2013) 'Multi-organisational coordination for disaster recovery: the story of post-tsunami Tamil Nadu, India'. International Journal of Disaster Risk Reduction. 4 (June). pp. 82-9I.

Reed, M.S. et al. (2010) 'What is social learning?'. Ecology and Society. I5(4). ri. https://www.ecology andsociety.org/volis/iss4/respi/ (last accessed on I2 November 2018).

Rodrik, D. (20I4) 'When ideas trump interests: preferences, worldviews, and policy innovations'. Journal of Economic Perspectives. 28(I). pp. 189-208.

Saunders, W.S.A. and J.S. Becker (20I5) 'A discussion of resilience and sustainability: land use planning recovery from the Canterbury earthquake sequence, New Zealand'. International Journal of Disaster Risk Reduction. I4(I). pp. 73-8I.

Schad, I. et al. (20I2) 'Why do people not learn from flood disasters? Evidence from Vietnam's northwestern mountains'. Natural Hazards. 62 (2). pp. 22I-24I.

Shove, E. (2010) 'Beyond the ABC: climate change policy and theories of social change'. Environment and Planning A: Economy and Space. 42 (6). pp. I273-I285.

Spijker, S.N. and C. Parra (2018) 'Knitting green spaces with the threads of social innovation in Groningen and London'. Journal of Environmental Planning and Management. 6I(5-6). pp. IOI I-IO32.

Swyngedouw, E. (2005) 'Governance innovation and the citizen: the Janus face of governance-beyondthe-state'. Urban Studies. 42 (I I). pp. I99I-2006.

Tidball, K.G., E. Krasny, E. Svendsen, L. Campbell, and K. Helphand (2010) 'Stewardship, learning, and memory in disaster resilience'. Environmental Education Research. I6(5-6). pp. 59I-609.

Tierney, K. (2012) 'Disaster governance: social, political and economic dimensions'. Annual Review of Environmental Resources. 37(I). pp. 34I-363.

UNISDR (United Nations Office for Disaster Risk Reduction) (20I5) Sendai Framework for Disaster Risk Reduction 2015-2030. https://www.unisdr.org/files/4329I_sendaiframeworkfordrren.pdf (last accessed on 5 December 2018).

UNISDR (2017) 'Terminology'. https://www.unisdr.org/we/inform/terminology (last accessed on I2 November 20I8).

Wisner, B., P. Blaikie, T. Cannon, and I. Davis (2004) At Risk: Natural Hazards, People's Vulnerability and Disasters. Second edition. Routledge, London. 